\title{
RESPONSE TO BEAVAN ATHFIELD'S “COMMENT ON 'DIET-DERIVED VARIATIONS IN RADIOCARBON AND STABLE ISOTOPES: A CASE STUDY FROM SHAG RIVER MOUTH, NEW ZEALAND'”
}

\author{
Atholl Anderson \\ Department of Archaeology and Natural History, Research School of Pacific and Asian Studies, Australian National \\ University, Canberra ACT 0200, Australia. Email: aja@coombs.anu.edu.au. \\ Thomas Higham \\ Oxford Radiocarbon Accelerator Unit, Research Laboratory for Archaeology and the History of Art, Dyson Perrins Building, \\ South Parks Road, Oxford OX1 3QY, England. Email: thomas.higham@rlaha.ox.ac.uk.
}

Beavan Athfield (2006) has commented on our recent paper in this journal (Higham et al. 2005). In our opinion, both in her response and in Beavan Athfield (2004) she misrepresents the evidence and conclusions presented by Anderson (2000). She claims (Beavan Athfield 2006:117) that Anderson's (2000) Figure 6, which is reproduced as Beavan Athfield's (2004) Figure 1, shows that ages of ancient rat bone gelatin in 1995-1996 (NZA numbers 4000-6000) were exclusively earlier than about 1000 BP, while those from 1997 onward (NZA numbers 7000+) were exclusively later than about 1000 BP. Beavan Athfield asserts that this is the result of Anderson (2000) ignoring 9 published accelerator mass spectrometry (AMS) results from 1995-1996 that were younger than about 900 BP. These would be serious claims of poor scholarship, were they substantiated, but in fact, Anderson $(2000,2004)$ never asserted that the AMS results were distributed so exclusively, nor did he fail to take account of all published results.

We believe this can all be explained by Beavan Athfield's (2006) misunderstanding of our Figure 6 . Anderson's (2000) Figure 6 showed exponentially weighted moving averages of AMS ages plotted against the sequence of NZA numbers. That is, it showed the general trend in age estimation, not the specific AMS radiocarbon results. This point is made explicit both in the text (Anderson 2000:24850) and the caption ("Exponentionally weighted moving averages AMS ages plotted by NZA number sequence") referring to Figure 6. It is also obvious from the narrowed age distribution, about 1300-500 BP, that this is not a plot of the actual AMS results, which extended from about 2200-200 BP. The specific AMS ages on which Figure 6 was based were plotted variously by Anderson (2000) in Figures 1-5, of which Figure 4 clearly shows the 9 published AMS ages from NZA 4000-6000 (i.e. 1995-1996), which were younger than about 1000 BP (in Figure 1, we show essentially the same figure as produced in Anderson [2000]). The archaeological examples of these were listed in Table 1 (Anderson 2000:249), and it was noted additionally that Figure 6 included all the results from the archaeological and natural sites dated by Rafter Radiocarbon Laboratory (Anderson 2000: 248).

It is also apparent that Beavan Athfield (2006:119) appears to disregard the argument (Anderson 2004) that the AMS age disconformity in Rafter Radiocarbon Laboratory results on ancient Rattus exulans gelatin could not be attributed to a sample submission policy. The actual origin of this idea appears to have been informal conjecture by Robert Hedges to Anderson (2000:251). We believe that to the contrary, there is very strong evidence that such a policy did not and could not have operarted (Anderson 2004). 


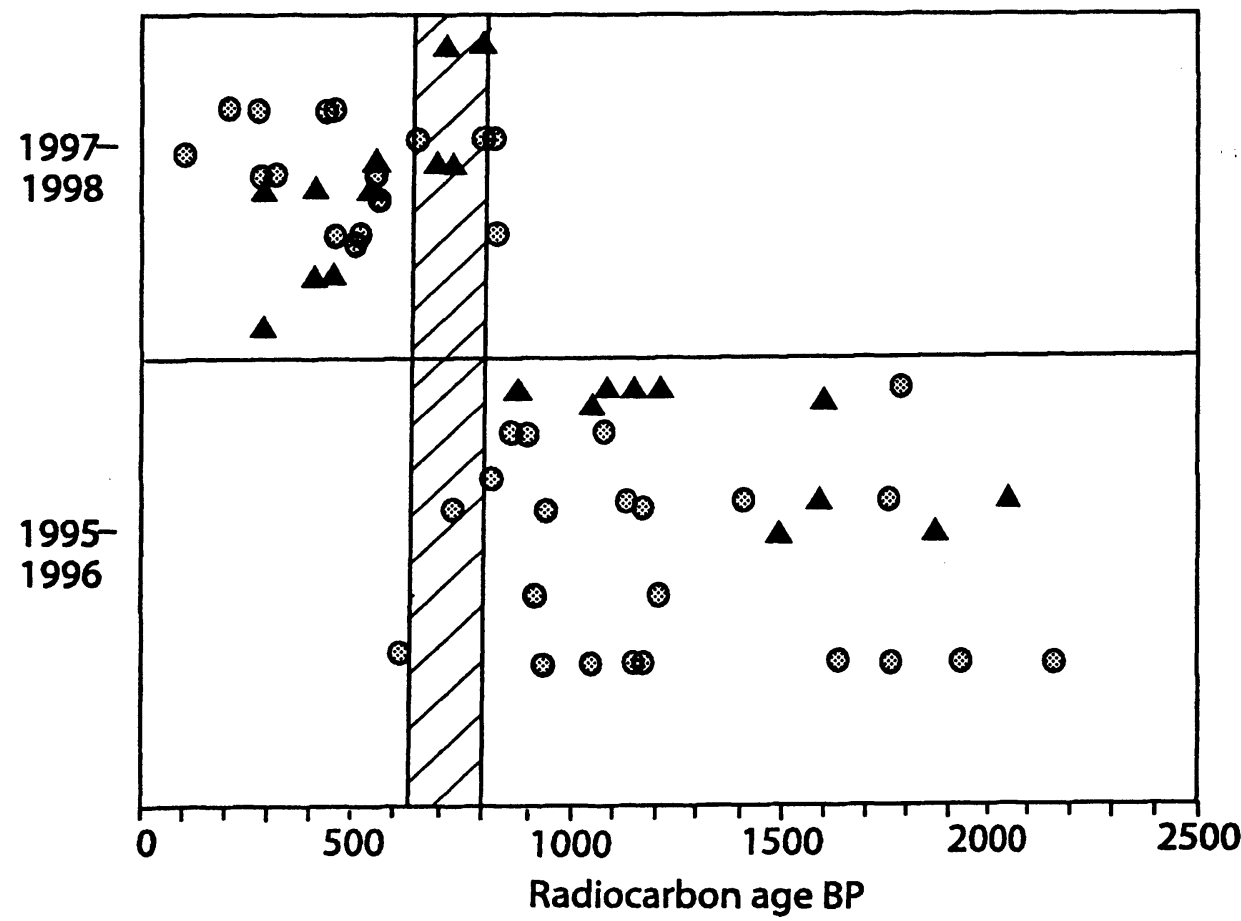

Figure 1 Plot of ${ }^{14} \mathrm{C}$ determinations of rat bone gelatin processed at the Rafter Radiocarbon Laboratory, 19951998. The dates are divided between those produced between 1995-1996 and those from 1997-1998. They are plotted in order of production, with dates lowest on the $y$ axis processed earlier than those higher up (see Anderson 2000). Dates from 1995-1996 correspond with NZA numbers ranging up to 7000. Samples from natural sites are shown as circles while triangles denote archaeological samples. Note the 9 AMS determinations very clearly plotted in the 1995-1996 group that are <950 BP (contra Beavan Athfield 2006). Figure originally produced in Anderson (2004) and reproduced with permission.

In summary, Beavan Athfield's $(2004,2006)$ comments do not adequately approach the matters at issue, which remain: 1) why is there an age disconformity in Rafter Radiocarbon Laboratory AMS ages on ancient Rattus exulans gelatin between results from 1994-1996 and those from all subsequent years to date? and 2) why is the same trend of age disconformity apparent in AMS ages from the unrelated sample universes of archaeological sites and natural cave scatters?

\section{REFERENCES}

Anderson AJ. 2000. Differential reliability of ${ }^{14} \mathrm{C}$ AMS ages of Rattus exulans bone gelatin in South Pacific prehistory. Journal of the Royal Society of New Zealand 30(3):243-61.

Anderson AJ. 2004. The age disconformity in AMS radiocarbon results on Rattus exulans bone. New Zealand Journal of Archaeology 24(2002):149-56.

Beavan Athfield N. 2004. Reliability of ${ }^{14} \mathrm{C}$ AMS dating of rat and bird bone: implications for the timing of New Zealand Holocene vertebrate extinctions. In: Higham TFG, Bronk Ramsey C, Owen DC, editors. Radiocarbon and Archeaeology: Proceedings of the
Fourth Symposium, Oxford 2002. Oxford University School of Archaeology Monograph 62. Oxford: Oxbow Books. p 105-18.

Beavan Athfield N. 2006. Comment on "Diet-derived variations in radiocarbon and stable isotopes: a case study from Shag River Mouth, New Zealand." Radiocarbon 48(1): 117-21.

Higham TFG, Anderson AJ, Bronk Ramsey C, Tompkins C. 2005. Diet-derived variations in radiocarbon and stable isotopes: a case study from Shag River Mouth, New Zealand. Radiocarbon 47(3):1-9. 